\title{
限界状態確率に基づく設計荷重の組合せと荷重係数の一決定法

\author{
DETERMINATION OF DESIGN LOAD COMBINATION AND LOAD FACTORS \\ ON THE BASIS OF LIMIT STATE PROBABILITIES
}

\author{
篠塚正宣* ·久保雅邦** \\ By Masanobu SHINOZUKA and Masakuni KUBO
}

\begin{abstract}
A rational procedure for determining design load combination and safety format is proposed, in which reliability-based structural design is developed on the basis of limit state probabilities. Load factors or safety factors associated with each design load combination in a safety format are optimized numerically through the objective function so that uniform level of structural reliabilities evaluated by limit state probability can be realized to the target, regardless of structural types and dimensions. Conceptual diagram of limit state probabilities is introduced to interpret the structural reliability, and the methodology to estimate the factors is showed with numerical examples using structural models and load combinations.
\end{abstract}

Keyroords : reliability, load combination, load factors, probability

\section{1. まえがき}

一般に,構造物の設計では死荷重や活荷重のみならず, 風, 温度, 地震等の影響によるさまざまな組合せ荷重を 考虑しなければならない1). しかも，諸元の異なる各種 の構造物や着目する限界状態ごとに，それぞれ支配的な 荷重の種類や荷重状態が異なる可能性がある.したがっ て,このような組合せ荷重を受ける種々の構造物に対し て, その形式や諸元等にかかわらずできるだけ均一な信 頼性をもたらす設計を行うには，異種荷重が同時に作用 することによって起こる構造物の限界状態を, 確率論的 にみて均等に評価する必要がある.

荷重係数体系の設計照査式を用いる限界状態設計法 は,この点に関して構造物の信頼性評価を取り入れるこ とによって, 従来の経験工学的な信頼性評価に基づく設 計法に比べてより合理的な設計ができると考えられてい る $^{2), 3)}$. すでに，欧米諸国ではこのような設計法が実用 化されており").5), わが国においてもコンクリート構造 物や道路橋の設計規準がその様式に改訂されつつあ

* 正会員 Ph.D. Columbia 大学教授 土木工学工業力学教 室 (Columbia Univ., 610, New York, N. Y., 10027, U. S. A.)

** 正会員 工修 (株) 綜合技術コンサルタント技術部課長 （ ₹533 大阪市東淀川区東中島 3-5-9）
$3^{6), 7)}$. ところが, 実際の設計照査に考慮すべき荷重組 合せの種類を選定するとともに，それぞれに対して必要 な設計安全率や荷重係数の値を算定するための基本的な 考え方や手法が, 必ずしも確立していない.これまで, 線形化 2 次モーメント法 ${ }^{8)}$ や現行の設計にキャリブレー ションする方法 ${ }^{91,10)}$ があり，たとえばある構造物に作用 する一組の組合せ荷重に着目し, 各荷重の不確定性に応 じた荷重係数を算定したり，あるいは現行の設計に整合 させながら，いくつかの構造物に対して均一な信頼性を もたらすような一組の荷重係数を算定することができる ようになってはいる.しかしながら, 実際の構造物設計 に対しては，考虑すべきさまざまな組合せ荷重の全体に 対してこのような評価を行う必要があると思われる.

本研究では, 構造物の安全性や使用性の大きさを限界 状態確率によって表わし，これがある目標値のまわりに 均等化するのが望ましいという考え方に基づいて, 荷重 組合せの種類と荷重係数を評価する手法を導入し，より 合理的な荷重係数体系の設計法を確立するための基礎資 料を求めた.この手法では, 目的関数としてすでにこの 種の規準策定に使われているの亡同様の関数を利用し, 対象亡する各種の構造物に作用する荷重の確率論的な組 合せ解析に基づいて, 必要な荷重係数を数値的に算定す る. 目的関数の値を最小化するという点で, 基本的には 
上記したキャリブレーションによる方法と同様の考え方 に基づいているが, 対象とする構造物や部材の諸元, あ るいは照查すべき限界状態の種類や目標とする信頼性の 水準，さらにはこれを支配する荷重やその組合せの種類 といった多種多様の項目に対して, 実際の設計照査で行 う手順を踏まえ，その中で目標とする構造物の安全性や 使用性を確保するようにした．対象とする構造物や荷重 の種類および個数にもよるが，比較的簡単な計算によっ て必要とする荷重係数さらには荷重組合せの種類を評価 することができ，具体的な設計体系を策定するうえで有 用な方法であると思われる，なお，構造物の安全性や使 用性に影響を及ぼす不確定性は，荷重だけでなく部材強 度のばらつきやその他の要因にも起因すると考えられる が, 本研究ではそれらのうち主要なものとして荷重のば らつきのみを考えた．また，目標とする限界状態確率の 大きさは，現行設計法の結果などを用いて仮定するもの とした.

すでに, 本研究の評価手法に沿った荷重組合せの解析

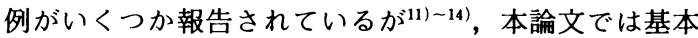
的な考え方 ${ }^{15)}$ をあらためて整理し，より実用的な評価 手法を検討するとともに，簡単な荷重と構造物のモデル を用いた計算例によってその妥当性を確認した結果を示 す.

\section{2. 組合せ荷重による限界状態確率}

\section{（1）組合せ荷重の種類と設計照査式の定義}

構造物の設計に考虑すべき荷重の大きさと荷重組合せ の種類を設定するにあたっては，これを規定する設計規 準が適用される構造物の種類や諸元等を想定し，そこに 予測されるさまざまな荷重状態を考虑しなければならな い. その際，対象とする各荷重について，構造物の限界 状態にとって有意な荷重効果をもたらす荷重状態だけを 考慮すればよく, 荷重の発生特性および強度特性の中で 明らかに有意でない状態を無視すると，相互に排反な荷 重組合せの種類を限定することができる.

いま，構造物として一般的な道路橋の上部構造と下部 構造とを念頭に置き, 部材の使用限界状態や終局限界状 態に対する設計照査において主要な荷重と考えられる, 死荷重 $(D)$, 活荷重 $(L)$ ，風荷重 $(W)$ および地震荷 重 $(E)$ のみを代表的に取り上げる．もちろん，実際の 設計例では, これらのほかに温度荷重や架設荷重等さま ざまな荷重が問題になることもあり，必要に応じて対象 とする荷重の種類を設定しなければならないが，ここで は上記した 4 つの荷重のみを対象にしてその荷重組合せ について議論する。

橋梁の供用期間 $T_{0}$ を考え，その間における各荷重の 発生特性および強度特性について有意な荷重状態を考え

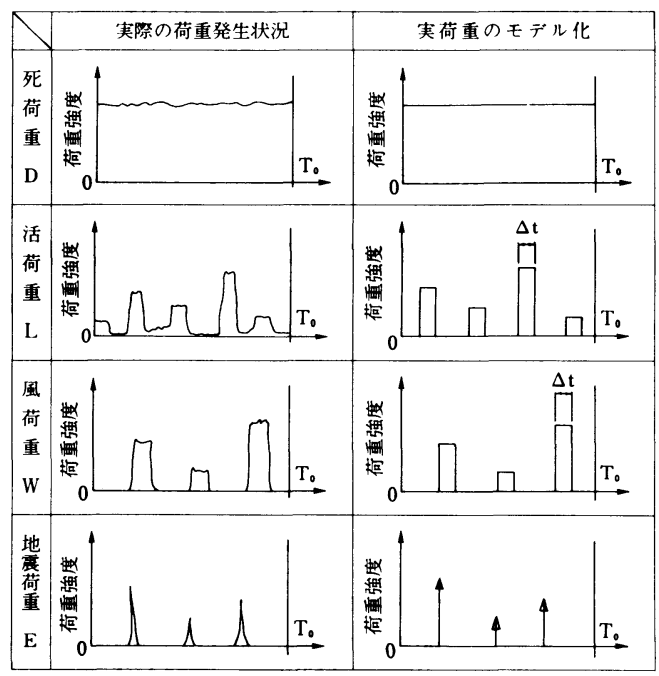

図一1 対象とする実荷重のモデル化

表一1 実荷重の組合せケース

\begin{tabular}{|c|c|c|c|}
\hline$x$ & 荷重組合せ & 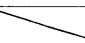 & 荷重組合せ \\
\hline Load- 0 & D & Load- 4 & $\mathrm{D}+\mathrm{L}+\mathrm{W}$ \\
\hline$"-1$ & $\mathrm{D}+\mathrm{L}$ & $"-5$ & $\mathrm{D}+\mathrm{L}+\mathrm{E}$ \\
\hline$"-2$ & $\mathrm{D}+\mathrm{W}$ & $"-6$ & $D+W+E$ \\
\hline$"-3$ & $\mathrm{D}+\mathrm{E}$ & $"=-7$ & $\mathrm{D}+\mathrm{L}+\mathrm{W}+\mathrm{E}$ \\
\hline
\end{tabular}

ると，実荷重のモデル化をたとえば図一1のように表わ すことができる．死荷重は相対的に不確定性が小さく， 供用期間を通して恒常的に作用し，その荷重強度は一定 とする．他の荷重では，それぞれ有意な荷重強度となる 状態が断続的に発生し，一回の発生について活荷重と風 荷重では便宜的に同一の継続時間 $\Delta t$ があり, 地震荷重 のそれは $\Delta t$ に比べてさらに短いものとする．また，各 荷重の強度は異種荷重間のみならず同一荷重間において も，確率的にすべて独立とする．その結果，構造物に作 用する荷重状態は，表一1に示すように 8 種類の相互に 排反な組合せ荷重となり，これを一般的に実荷重の組合 せケース Load- $i(i=0,1,2, \cdots \cdots \cdots, 7)$ とおく.

一方，設計荷重の組合せケースを一般にCode- $j(j$ $=1,2, \cdots \cdots .$.$) とおき，これによる限界状態設計法の設$ 計照査式を次式によって定義する.

$$
\begin{aligned}
& R_{n} \geqq \sum_{m} \alpha_{m} \cdot \gamma_{m} \cdot m^{*} \\
& \quad(m=D, L, W, E, \quad j=1,2, \cdots \cdots) \cdots(1)
\end{aligned}
$$

ここに, $R_{n}$ は部材の限界状態を表わす公称強度， $\alpha_{m}$ は 荷重 $m(m=D, L, W, E)$ の荷重効果への変換係数, $\gamma_{m}$ は Code- $j$ に含まれる荷重 $m$ の荷重係数, $m^{*}$ は荷 重 $m$ の設計荷重強度をそれぞれ表わす． $R_{n}$ と $m^{*}$ は確 定値とし, それぞれ強度と荷重の特性値として与えられ るものとする．また， $\alpha_{m}$ は構造物の特性によって表わ 
される変数で，その構造物を設計した段階では確定值と して計算される.これに対して， $\gamma_{m}$ 深これから求めよ うとする未知変数となる.

式（1）で明らかなように, 荷重と荷重効果との間に は線形関係があるものと仮定する.もし, 非線形領域で議 論しなければならない限界状態を対象にする場合には, 式（1）に換えて別の定義を必要とするが，この点につ いては今後の大きな課題と考えられる. また，荷重係数 体系の設計照查式としては, 式（1）の定義に加えて左 辺に強度係数や右辺に全体係数を用いることもある が16)，ここでは説明を簡単にするために上記の表現式を 用いる。

式（1）の照査によれば, すべての設計荷重組合せ Code- $j(j=1,2, \cdots \cdots)$ について, 設計荷重を荷重係 数倍して得られる荷重効果の和が, 着目する限界状態の 公称強度より等しいか小さくなることを要求している.

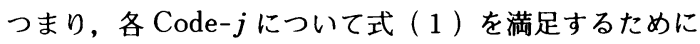
必要な部材断面のうち, 最も大きな断面を設計断面とし て採用し，その場合の荷重組合せケースがその部材の設 計を支配する設計荷重組合せとなる，このように，ここ では式（1）の形によって照査することができる荷重状 態と限界状態のみを対象にする，具体的には，表一1に 示した実荷重の組合せのもとで, 荷重効果の最大值が問 題となる使用限界状態を超えるような変形や引張破壊な だの終局限界状態を考えることにする，なお，各 Code- $j$ ごとに $\gamma_{m}$, の值を同じにして左辺に移せば, 式

（1）は現行の許容応力度設計法による設計照査式と形 式的にも原理的にも同じ意味をもつことになる.さらに， 荷重係数だけでなく強度係数や全体係数を考える場合に は, その分の未知変数を増やすことによって, 式 (1) に関するここでの議論を容易に拡張することができる.

ところで, Code- $j$ に含まれる荷重の種類は, 当然な がらこれに対応する実荷重の組合せ Load- $i$ (ただし,

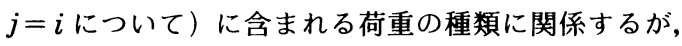
Load- $i$ のすべてについてそれぞれ対応する Code- $j$ が 必要となるわけではない，明らかに設計照査で断面決定 に寄与することがないような組合せ荷重，たとえば表一 1 に示した Load-0 に対応するものなどは，設計照査式

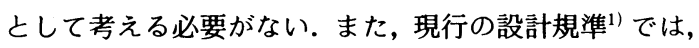
同じく Load-7 のような組合せ荷重は発生する確率が非 常に小さいという理由から，それに対応する設計荷重の 組合せを規定していない.

そこで, 必要とする設計荷重の組合せケースを選定す るために, 表一 1 に示した 8 種類から Load-0 を除く 7 種類の荷重組合せに対応する設計荷重の組合せを考え， 表一2に示すような設計照査式の中から考慮すべき Code- $j(j=1,2, \cdots \cdots)$ を検討する.
表一2 設計照本式の定耧

\begin{tabular}{|c|l|}
\hline & \multicolumn{1}{|c|}{ 設 計 照 査 式 } \\
\hline Code- 1 & $\mathrm{R}_{\mathrm{n}} \geqq \alpha_{\mathrm{D}} r_{\mathrm{D} 1} \mathrm{D}^{*}+\alpha_{\mathrm{L}} r_{\mathrm{L} 1} \mathrm{~L}^{*}$ \\
\hline$"-2$ & $\mathrm{R}_{\mathrm{n}} \geqq \alpha_{\mathrm{D}} r_{\mathrm{D} 2} \mathrm{D}^{*}+\alpha_{\mathrm{w}} r_{\mathrm{w} 2} \mathrm{~W}^{*}$ \\
\hline$"-3$ & $\mathrm{R}_{\mathrm{n}} \geqq \alpha_{\mathrm{D}} r_{\mathrm{D} 3} \mathrm{D}^{*}+\alpha_{\mathrm{E}} r_{\mathrm{E} 3} \mathrm{E}^{*}$ \\
\hline$"-4$ & $\mathrm{R}_{\mathrm{n}} \geqq \alpha_{\mathrm{D}} r_{\mathrm{D} 4} \mathrm{D}^{*}+\alpha_{\mathrm{L}} r_{\mathrm{L} 4} \mathrm{~L}^{*}+\alpha_{\mathrm{w}} r_{\mathrm{w}} \mathrm{W}^{*}$ \\
\hline$"-5$ & $\mathrm{R}_{\mathrm{n}} \geqq \alpha_{\mathrm{D}} r_{\mathrm{D} s} \mathrm{D}^{*}+\alpha_{\mathrm{L}} r_{\mathrm{L} s} \mathrm{~L}^{*}+\alpha_{\mathrm{E}} r_{\mathrm{E} s} \mathrm{E}^{*}$ \\
\hline$"-6$ & $\mathrm{R}_{\mathrm{n}} \geqq \alpha_{\mathrm{D}} r_{\mathrm{D} 6} \mathrm{D}^{*}+\alpha_{\mathrm{w}} r_{\mathrm{w} 6} \mathrm{~W}^{*}+\alpha_{\mathrm{E}} r_{\mathrm{E} 6} \mathrm{E}^{*}$ \\
\hline$"-7$ & $\mathrm{R}_{\mathrm{n}} \geqq \alpha_{\mathrm{D}} r_{\mathrm{D} 7} \mathrm{D}^{*}+\alpha_{\mathrm{L}} r_{\mathrm{L},} \mathrm{L}^{*}+\alpha_{\mathrm{w}} r_{\mathrm{w} 7} \mathrm{~W}^{*}+\alpha_{\mathrm{E}} r_{\mathrm{E} 7} \mathrm{E}^{*}$ \\
\hline
\end{tabular}

\section{（2）限界状態確率の算定}

実荷重が作用する構造物のある部材に着目し，その供 用期間中に作用するすべての実荷重組合せによって生ず る荷重効果の最大値を確率変数 $X$ で表わす.この変数 $X$ は荷重 $m(m=D, L, W, E)$ 之, 構造物の特性に よって表わされる一般的な関数 $G(\cdot)$ を用いて表わ すことができる.

$X=G(D, L, W, E)$

前記したように, いま荷重と荷重効果との間には線形 関数を仮定しており, かつ各荷重 $m$ の設計荷重 $m^{*}$ 之 その実荷重との作用位置および作用方向がともに同じで あれば, 式 $(1)$ の定義を用いてこの関数 $G=G(\cdot)$ を次のように考えることができる.

$$
G=\max \text { of }\left[\sum_{m} \alpha_{m} \cdot m\right] \quad(m=D, L, W, E)
$$

したがって,このような荷重効果の最大值が, 部材の限 界状態を表わす状態変数 $x$ を超えるとき,すなわち

$$
x-G(D, L, W, E) \leqq 0
$$

は, 部材が限界状態に入ったことを示し, 式 (4) の状 態が発生する確率を, ここでは限界状態 $x$ に対する限 界状態確率 (Limit State Probability) $P(x)$ とよぶ ことにする.

限界状態確率の大きさは, 構造物の安全性や使用性の 大きさを定量的に表わす民度となり ${ }^{17)}$, 設計された構造 物の諸元や部材強度と荷重の確率特性とを用いて求める ことができる.ここでは，図一1に示したようなモデル に基づき, Wen の Load Coincidence Method ${ }^{18)}$ による 次式によってこれを求めることにする.

$$
P(x) \doteqdot 1-\exp \left\{\sum_{i=0}^{7}-n_{i} \cdot Q_{i}(x)\right\}
$$

ここに， $n_{i}$ は実荷重の組合せ Load- $i$ が供用期間中に 発生する期待回数, $Q_{i}(x)$ は Load $-i$ の組合せ荷重が 一回発生したとして，そのときの荷重効果の和が状態変 数 $x$ を超過する確率をそれぞれ表わす.

式 $(5)$ による方法は, 時間的に変動する荷重の組合 せ解析において実用的な近似解を与えるが ${ }^{19}$, 各荷重の 強度分布特性から $Q_{i}(x)$ を求めるにあたって確率変 数の和を計算する必要があり，一般には多重のたたみ込 
み積分あるいはモンテカルロシミュレーションによる計 算が必要となる．これに対して本研究では，各荷重の強 度分布として正規分布を仮定し，正規分布の再現性を利 用して $Q_{i}(x)$ を理論的に求める. その結果を式（5） へ代入して $P(x)$ を求める. このような正規分布の仮 定が，実際の荷重特性を必ずしも正確に表わすとはいえ ないが, 本研究の目的とする荷重組合せの種類と荷重係 数を決定する手法の原理を明らかにするうえで，1つの 計算例として有用なものと考えられる.

\section{3. 荷重係数の評価法}

\section{（1）最適な荷重係数の考え方}

設計されたある部材の限界状態確率 $P(x)$ を求める と，たとえば図一2の模式図に示すように単調減少する 1 つの曲線 $\mathrm{B}$ が得られる．同図の点線は，それぞれ実 荷重組合せ Load- $i$ のみが作用したときの限界状態確率 を表わし，これらを式（5）によって合計したものが曲 線 $\mathrm{B}$ となるが, 状態変数 $x$ の存在範囲に応じて, それ ぞれ限界状態確率が最も大きくなる実荷重組合せの種類 が異なる可能性を示している，ただし，ここでは簡単の ために Load-1〜Load-3 のみを用いている. 同様にし て, 他の構造物あるいは部材についてこれを求めると, 構造諸元や支配的な荷重効果の違いによって, 上記の曲 線 B とは少し異なる別の曲線が得られる.

一方, 構造物の設計にあたって必要な信頼性の概念は, このような曲線 B の集まりに対して 1 つの目標を示す 曲線 $\mathrm{A}$ があり，考虑すべきすべての構造物あるいは部 材に対して曲線 B を曲線 A にできるだけ近づけること によって表わされる．曲線 A は，目標とする信頼性の 大きさを限界状態確率によって表わしたものであり，設 計照査式を求めるにあたって構造物の経済性, 社会性, その他の要因を加味しながら設定しておくものとする. その際, 対象とする構造物あるいは部材の種類や, 上記 したように限界状態確率が最も大きくなる実荷重組合せ の種類に応じて，目標とする曲線 $\mathrm{A}$ を変えることもで きる，つまり，構造物の重要度やその信頼性を支配する

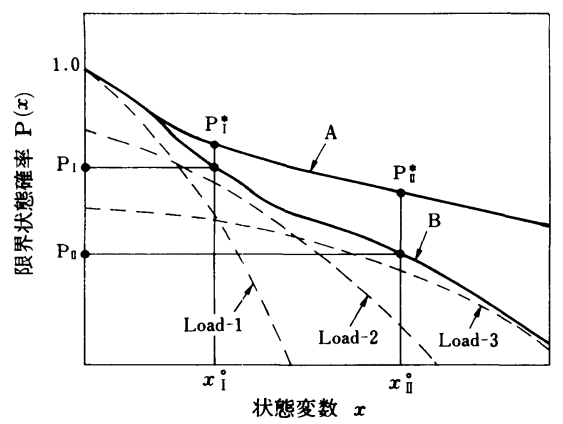

图一2 限界状態確本とその目模
荷重の違いに対して異なる目標値を与えるもので，一般 には設計規準の中にこのような配虑が暗然のうちに認め られている. しかしながら，この点は式（1）に関して 言及したように全体係数の問題と考えられ，ここでは荷 重係数のみに着目する意味で, 対象とする構造物と荷重 のすべてに対して目標とする曲線 A をただ1つ与える ことにする.

理想的には, 状態変数 $x$ の全範曲において曲線 $\mathrm{B}$ を 曲線 A に近づけることがより均一な信頼性を与えるが, 構造物の実際面や設計照查の実用性からすると, 状態変 数の中で各種の限界状態を表わす特定の值，たとえば図 -2の $x_{I}^{\circ}$ や $x_{I}^{\circ}$ など点においてのみ所定の信頼性を保 持すればよいものと考えられる.ここで， $x_{I}^{\circ} や x_{I}^{\circ}$ はそ れぞれ使用限界状態や終局限界状態などを表わす特性值 とし，物理的な意味をもつ公称值として設定する．たと えば, 状態変数が部材の引張応力度を表わすとすれば, 弾性限界や降伏強度などの公称強度がそれぞれ $x_{I}^{\circ} や x_{n}^{\circ}$ に相当し，式（1）の $R_{n}$ はこれを一般的に表わしたも のにほかならない.

ところで, 考慮すべき限界状態の数とその特性值とは, 着目する状態変数に応じて設定する必要があり, 通常は $1 つ の$ 状態変数について 1 ～ 3 個の限界状態を特定すれ ばよいと思われる. その際，1つの状態変数について 2 つ以上の限界状態を考虑する場合には，それぞれに対し て式（1）の設計照査を行うものとする，つまり，限界 状態 $x_{I}^{\circ}$ について一組の Code- $j_{I}\left(j_{I}=1,2, \cdots \cdots\right)$ が

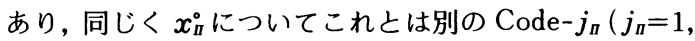
2 ，…..) があって，それらのすべてを用いて式（1） の設計照査を行い, その結果必要な部材断面のうち最大 となる設計照査式によって設計断面を決定する．たとえ ば，ある構造物では $x_{I}^{\circ}$ の設計照査において断面が決定 し，これが $x_{n}^{\circ}$ に対しては十分に余裕をもつような断面 となることがある.この場合の設計断面が，2つの限界 状態について不必要な余裕をもたないことが経済性から みて望ましいが, 式（１）のようなレベルＩの方法によっ て設計照査を行う限りにおいては，この点を設計規準の 中で規定することはできない。それは，構造物に必要な 諸元と設計者の判断とによって決定される.したがって， 2 つ以上の限界状態を考慮する場合の荷重係数を評価す

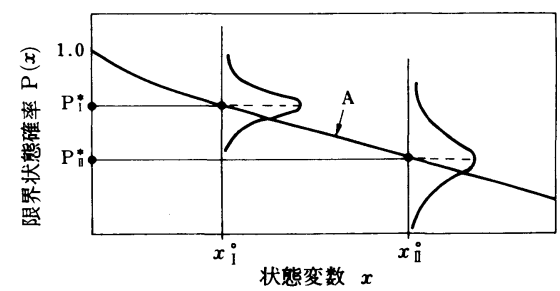

図一3 限界状蟹䝔率のばらつき 
るにあたっては，それらを独立に扱うものとする．この ことは, 異なる 2 つ状態変数 $x, y$ における限界状態 $x^{\circ}, y^{\circ}$ についても同様である.

そこで, 対象とする各種の構造物について, $x_{i}^{\circ}$ や $x_{\pi}^{\circ}$ における限界状態確率 $P_{I}$ や $P_{n}$ が, その目標值 $P_{I}^{*}$ や $P_{n}^{*}$ のまわりにばらつく様子を同一平面上で概念的に示 すと，たとえば図一-3のようになる．多くは目標值の周 辺に集まるが，一部の構造物では目標值よりも大きくあ るいは小さくなる，したがって，構造物の信頼性を均一

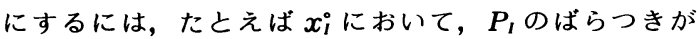
$P_{I}^{*}$ のまわりに最小化するように一組の設計荷重組合せ ケース Code- $j_{I}\left(j_{I}=1,2, \cdots \cdots\right)$ の荷重係数を算定す ればよいことになる.

\section{（2）最適化のアルゴリズム}

以上の考え方に基づいて，考慮すべきいくつかの設計 荷重組合せケース Code- $j(j=1,2, \cdots \cdots)$ の最適な 荷重係数を算定する手法を以下に示す。ただし，この段 階では Code- $j$ の種類は与えられているものとする.

(1) 設計照査式を適用する範囲の構造物の中から，代 表的な構造諸元を有するものをその使用頻度等に応じて 選定する.これを構造物 $S_{k}(k=1,2, \cdots \cdots, N)$ とお $<$.

(2) 照査すべき構造物の限界状態として, 特性値 $x^{\circ}$ および目標とする限界状態確率 $P^{*}$ を設定する.

（3）考慮すべき荷重 $m$ の設計荷重強度 $m^{*}(m=D$, $L, W, E)$ を設定する.

(4) 各構造物 $S_{\boldsymbol{k}}$ をすべての設計照査式を用いて設計 する. その際，各荷重係数にはある值が設定されている ものとする. Code- $j$ を用いて $S_{k}$ を設計したときに， ちょうど式（1）の等号が成り立つような部材断面の大 きさを $Z_{k j}$ とすると, 次式によって求められる.

$$
\begin{aligned}
& Z_{k j}=\left\{\sum_{m} \beta_{k m} \cdot \gamma_{m j} \cdot m^{*}\right\} / x^{\circ} \cdot \\
\text { ここに, } &
\end{aligned}
$$

$$
\beta_{k m}=\alpha_{k m} \cdot Z_{k s}
$$

ただし， $\alpha_{k m}$ は式（1）の $\alpha_{m}$ に相当するが，構造物 $S_{k}$ の変換係数であることを示す.したがって，各構造物の 設計断面 $Z_{\boldsymbol{k}}$ は，その值を最大にする設計照査式によっ て決定される。

$$
Z_{k}=\max \text { of }\left[Z_{k J}\right] \quad(j=1,2 \text {, }
$$

(5) 設計された構造物 $S_{\boldsymbol{k}}$ が，すべての実荷重組合せ Load- $i(i=0,1, \cdots \cdots, 7)$ を受ける場合の限界状態 確率 $P^{(k)}=P\left(x^{\circ}\right)$ を算出し，これを用いて目標値 $P^{*}$ との間に次式で定義される目的関数 $\Omega$ の值を求める.

$$
\Omega=\sum_{k=1}^{N}\left\{\frac{\log P^{(k)}-\log P^{*}}{\log P^{*}}\right\}^{2}
$$

(6) 目的関数 $\Omega$ は対数変換した $P^{(k)}$ と $P^{*}$ の差のば らつきの程度を表わし, すべての構造物 $S_{k}(k=1,2$,
， $N$ ）とすべての荷重組合せケース Code- $j(j=1$, $2 ， \cdots \cdots . .$.$) とに対してただ 1$ つ定義される. したがって， この $\Omega$ にはすべての荷重係数 $\gamma_{m j}$ を末知変数として含 み，次式を用いてこれを算定する。

$$
\frac{\partial \Omega}{\partial \gamma_{m j}}=0 \quad\left(\begin{array}{l}
m=D, L, W, E, \\
j=1,2, \cdots \cdots
\end{array}\right) .
$$

以上の算定手法において，一般に式 (10) は非常に複 雑な非線形連立方程式となり，その解を求めるのは容易 でない. 閉じた形で解くことはもちろんのこと，数值計 算による場合でも未知変数の数が多くなると加速度的に 困難さを増す．従来の解析ではこの点を解決するため に， $\Omega$ の等高線図を利用し，試行錯誤的方法によって 末知変数 $\gamma_{m j}$ の值を求めた ${ }^{11) \sim 14)}$. つまり，ステップ(4) で各荷重係数 $\gamma_{m}$, の值をいくつか仮定し，これを用いて ステップ(5)で $\Omega$ を算出する. その結果 $\Omega$ の等高線図を 作成して，その值が最小となるようにステップ(4)へ戻っ て $\gamma_{m j}$ の值を試行錯誤的に変える.

ところが，表一2に示した設計照査式のすべてに含ま れる末知変数の数は合計 19 個にもなり，あるいは現行 の設計規準に規定されているのと同じ種類の荷重組合せ ケース Code-1，-3，-4 のみを考虑する場合でも，それ らの中に含まれる未知変数の数は合計 7 個と多い. した がって，これだけ多くの未知変数を同時に独立変数とみ なして $\Omega$ の值を最小化するためには，膨大な計算が必 要になるとともに各変数の最適值をとらえにくい. そこ で，より実用的にステップ(4)〜 (6)の収束計算を行うため に，次のように算定手法を改善する。

求めようとするすべての荷重係数 $\gamma_{m s}$ にそれぞれある 值が設定されているとして, 式（6）によって各構造物 の $Z_{k J}$ を求める. 簡単のために, Code-1 Code-3 およ び構造物 $S_{1} \sim S_{10}$ のみを用いる場合を模式的に示すと, 一例として図-4のようになる．これを各構造物 $S_{k}$ ご とにみると，その設計断面 $Z_{k}$ は 3 つの $Z_{k J}$ のうちその

\begin{tabular}{|c|c|}
\hline Code- 1 が支配的な構造物 & $S_{1}, S_{2}, S_{10}$ \\
\hline Code- 2 が支配的な構造物 & $S_{3}, S_{4}, S_{8}, S_{9}$ \\
\hline Code- 3 が支配的な構造物 & $S_{5}, S_{6}, S_{7}$ \\
\hline
\end{tabular}
最大值にほかならず，これ以外の $Z_{k s}$ は上記した限界状

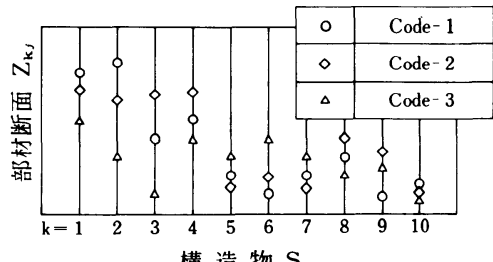

構造物 $\mathrm{S}_{\mathrm{k}}$

図一4 部材断面 $Z_{k}$, の一例

\section{表一3 各設計荷重組合せが支眍的な㮐造物}


態確率 $P^{(\boldsymbol{k})}$ を算定するうえで必要としない．言い換えれ

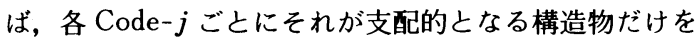
抽出し，その構造物をCode- $j$ のみを用いて設計した場 合の限界状態確率 $P_{j}^{(k)}$ を用いて式（9）の $\Omega$ を求める ことができる. 図一4に示した結果では，各 Code- $j(j$ $=1 ， 2 ， 3 ）$ が支配的となる構造物を抽出すると表一3 のようになる.

もし，表一3に示した結果が，式（10）のすべてを満 足するような荷重係数 $\gamma_{m}$ を用いて得られた結果と同じ ものであれば，これを用いて比較的容易に荷重係数の最

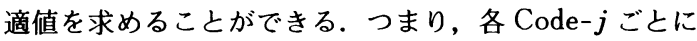
含まれる荷重係数のみを末知変数として式（10）の連立 方程式を解けばよい，表一2 の場合では，たかだか 2 4 個の末知変数に対して収束計算を行えばよいことにな り，上記したような 7〜19 個の未知変数を同時に扱う場 合に比べて，大幅に試行錯誤による計算過程を減らすこ とができる。

そこで，構造物 $S_{k}(k=1,2, \cdots \cdots, N)$ を各設計荷 重組合せケースごとに振り分ける.そのための 1 つの方 法としては，全く試行錯誤的にその振り分けを設定する 方法が考えられるが，対象とする構造物の数が比較的多 い場合には，漸近的な方法によって効率よく振り分ける ことが望ましい. 実際の構造物に対する現行の設計例, あるいはこれまでの荷重組合せについての試算例 ${ }^{14)}$ みると, 構造物の設計を支配する設計荷重組合せの種類 は許容応力度設計法や限界状態設計法にかかわらず, 目 標とする設計安全率や荷重係数の近傍では大きく変わる ものではない．このことは構造物の安全性や使用性を支 配する実荷重の組合せケースが, 構造物ごとにほぼ特定 していることからも推察することができよう.したがっ て，構造物ごとに支配的でない設計荷重組合せの種類を 次々と除去することによって, 必要な設計荷重組合せの ケースを特定すればよい. ステップ(4)〜(6)について，そ のための算定手法をまとめると次のようになる.

(4)-1 各 Code- $j$ に含まれる荷重係数 $\gamma_{m}$ の值を設定 し，これを用いて対象とする構造物 $S_{k}$ に対して $Z_{k J}$ を 求める. その際, 最初は各 Code- $j$ についてすべての構 造物を用いて行い, 次からは除去されて残った構造物の みを用いて行う.

(5)-1 上記の $Z_{k j}$ を用いて，すべての実荷重組合せ Load- $i$ による限界状態確率 $P_{j}^{(k)}$ を算出する.

(5)-2 各 Code- $j$ ごとに， $Z_{k J}$ の值が比較的小さく設 計を支配する可能性がない構造物 $S_{k}$ を除去し, 関係す る $P_{j}^{(k)}$ のみを用いて, 目標値との間に目的関数 $\Omega_{j}^{(k)}$ を求 める.

$$
\Omega_{j}^{(k)}=\sum_{k}^{(j)}\left\{\frac{\log P_{j}^{(k)}-\log P^{*}}{\log P^{*}}\right\}^{2}
$$

$$
(j=1,2, \cdots \cdots)
$$

ここに， $\sum_{k}^{(j)}$ はCode- $j$ に関して残った構造物 $S_{k}$ のみに ついて合計することを表わす.したがって，各 $Q_{j}^{(\boldsymbol{k})}$ の合 計を $\Omega^{\prime}$ と置き，これと式（9）の $\Omega$ との関係は次式と なる。

$$
\Omega \leqq \Omega^{\prime}=\sum_{j} \Omega_{j}^{(k)}
$$

(6)-1 各 Code- $j$ ごとに， $\Omega_{j}^{(k)}$ の值が最小となる荷重 係数 $\gamma_{m}$, の值を求め, その結果を用いてすべての構造物 $S_{k}$ を設計する.

(6)-2 各構造物 $S_{\boldsymbol{k}}$ ごとに，支配的な設計荷重組合せ Code- $j$ が, ステップ(5)-2でこれまでに除去したものに なっていないことを確認する。

以上のステップ(4)-1〜(6)-2 を, 各構造物 $S_{k}$ について ただ 1 つの設計荷重組合せケース Code- $j$ が特定するま で繰り返す。ただし，繰り返し計算の途中では式 (12) の不等号が成り立つ.というのは, 式 (11) の段階で構 造物 $S_{\boldsymbol{k}}$ がただ 1 つの Code- $j$ に特定していない場合に は，式 (12) による $\Omega_{j}^{(\boldsymbol{k})}$ の方がその分だけ大きくなる. しかし，各 $\Omega_{j}^{(\boldsymbol{k})}$ の值を最小化する段階では式 (12) の等 号が成り立つ必要はなく，最終的に各構造物にただ $1 つ$ の Code- $j$ が特定した段階で式 (12) の等号が成り立つ.

なお，構造物の重要度や荷重の地域特性を考虑する場 合には, 式（9）や式（11）に示した目的関数を修正す ることによって, 本研究の手法をそのまま拡張すること ができると考えているが, 詳細な点については今後の課 題として研究する必要がある.

\section{（3）設計荷重組合せの種類について}

上記の算定手法では設計荷重組合せ Code- $j(j=1$, $2, \cdots \cdots)$ の種類を限定しなかったが, 最適な荷重係数 を算定するにあたって, 表一 2 に示した 7 種類の設計荷 重組合せケースの中から, 設計照査に考慮すべき荷重組 合せの種類を選定する必要がある．そのための考え方と しては，まず表一1に示した実荷重組合せケースの中で 着目する限界状態に対して支配的となるもの，次にそれ に対応する設計荷重組合せケースを用いて設計照查を行 う場合，式（9）の目的関数 $\Omega$ の值を小さくするうえ で必要となるものを選定すべきと考えられる．言い換え れば, どの構造物の設計断面をも支配することがないか, あるいは支配的となっても他の設計荷重組合せケースと 同程度の影響しかもたない組合せケースを除去する．前 記したように，表一2のたとえばCode-7 が現行の設計 規準に規定されていないのはこのような見地に基づくも のと思われるが，これを除去するための判断が主として 経験則に基づいているため，その結果が妥当かどうかは 必ずしも明確ではない，ここでは，そのための数值的な 判断を下す必要があり, 上記した荷重係数の評価手法を 用いて計算例で具体的に検討する. 


\section{4. 計算例と考察}

\section{（1）荷重と槽造物のモデル}

前記した荷重係数の算定手法をより具体的に示すとと もに, 求める荷重係数体系の設計法と許容応力度設計法 とを比較するために, 簡単な荷重と構造物のモデルによ る計算例を示す。

荷重のモデルとして, 図一1に示したような死荷重 $(D)$, 活荷重 $(L)$, 䖝荷重 $(W)$ および地震荷重 $(E)$ を考え, その発生頻度と荷重強度の確率分布を図一 5 と 表一 4 のように仮定する. 図一 5 の横軸は荷重強度 $m$ をその平均値 $\bar{m}$ で規準化した結果を表わし, 縦軸は各 荷重が一回発生したときの荷重強度の分布を確率密度関 数 $f_{m}(y)$ によって表わしている. 死荷重の不確定性は 相対的に小さく, その設計荷重強度 $D^{*}$ と実荷重 $D$ と はともに平均值 $\bar{D}$ に等しいものとし，したがっていず れも確定值とする. 他の荷重では, 確率変数 $m / \bar{m}$ $(m=L, W, E)$ が前記したようにすべて正規分布に 従うものとする. それらの変動係数および設計荷重の大 きさ,さらに各荷重の再現期間 $T_{m}(m=L, W, E)$ および活荷重と風荷重の一回の継続時間 $\Delta t$ を表一 4 に 示したとおりとし, 橋梁の供用期間 $T_{0}=50$ 年を考える. これらの值は非常に大まかな近似ではあるが, 荷重の実 態調查結果 ${ }^{20)}$ などを参考にして仮定したものである. しかし, 定量的には必すしも現実の荷重および現行の設 計規準を表わすものではなく，各種の荷重組合せあるい は設計法の相対的な比較をするうえでのみ有用と考えら れる.

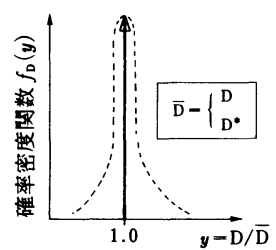

（a）死 荷 重

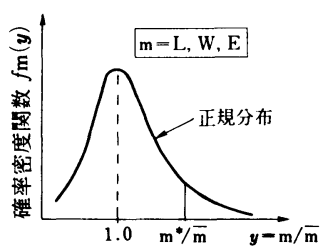

(b) その他の荷重
图一5 荷重の強度分布のモデル

\section{表一4 荷重モデルの設定什}

\begin{tabular}{|c|c|c|c|c|}
\hline & \multicolumn{2}{|c|}{ 実荷重 $\mathrm{m} / \overline{\mathrm{m}}$} & $\mathrm{m} \% \overline{\mathrm{m}}$ & 発生頻度 \\
\hline 死 荷 重 & 1.00 & - & 1.00 & $\longrightarrow$ \\
\hline 活荷重 & 正規分布 & $\begin{aligned} \mu & =1.00 \\
\sigma & =0.20\end{aligned}$ & 1.40 & $\begin{array}{l}\mathrm{T}_{\mathrm{L}}=1.00 \text { 月 } \\
\Delta \mathrm{t}=3.00 \text { 時間 }\end{array}$ \\
\hline 風荷重 & 正規分布 & $\begin{aligned} \mu & =1.00 \\
\sigma & =0.30\end{aligned}$ & 1.90 & $\begin{array}{l}\mathrm{T}_{\mathrm{w}}=1.00 \text { 年 } \\
\Delta \mathrm{t}=3.00 \text { 時間 }\end{array}$ \\
\hline 地袁荷重 & 正規分布 & $\begin{aligned} \mu & =1.00 \\
\sigma & =0.50\end{aligned}$ & 2.50 & $T_{E}=2.00$ 年 \\
\hline
\end{tabular}

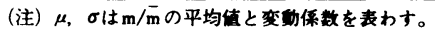

表—5 梏造物モデルの設定住

\begin{tabular}{|c|c|c|c|c|}
\hline 樓 造 物 & $d_{k D}$ & $\mathrm{~d}_{\mathrm{kL}}$ & $d_{k w}$ & $d_{k E}$ \\
\hline$S_{1}$ & 25 & 25 & 25 & 25 \\
\hline $\mathrm{S}_{2}$ & 10 & 20 & 30 & 40 \\
\hline $\mathrm{S}_{3}$ & 10 & 20 & 40 & 30 \\
\hline S. & 10 & 30 & 20 & 40 \\
\hline $\mathrm{S}_{5}$ & 10 & 30 & 40 & 20 \\
\hline S. & 10 & 40 & 20 & 30 \\
\hline $\mathrm{S}_{\text {, }}$ & 10 & 40 & 30 & 20 \\
\hline S. & 20 & 10 & 30 & 40 \\
\hline $\mathrm{S}$, & 20 & 10 & 40 & 30 \\
\hline$S_{10}$ & 20 & 30 & 10 & 40 \\
\hline$S_{11}$ & 20 & 30 & 40 & 10 \\
\hline$S_{12}$ & 20 & 40 & 10 & 30 \\
\hline$S_{13}$ & 20 & 40 & 30 & 10 \\
\hline$S_{14}$ & 30 & 10 & 20 & 40 \\
\hline$S_{15}$ & 30 & 10 & 40 & 20 \\
\hline$S_{16}$ & 30 & 20 & 10 & 40 \\
\hline $\mathrm{S}_{17}$ & 30 & 20 & 40 & 10 \\
\hline$S_{12}$ & 30 & 40 & 10 & 20 \\
\hline$S_{19}$ & 30 & 40 & 20 & 10 \\
\hline$S_{30}$ & 40 & 10 & 20 & 30 \\
\hline$S_{21}$ & 40 & 10 & 30 & 20 \\
\hline$S_{n z}$ & 40 & 20 & 10 & 30 \\
\hline $\mathrm{S}_{23}$ & 40 & 20 & 30 & 10 \\
\hline$S_{24}$ & 40 & 30 & 10 & 20 \\
\hline $\mathrm{S}_{25}$ & 40 & 30 & 20 & 10 \\
\hline
\end{tabular}

次に，構造物のモデルとして次式で表わされるパラ メーター $d_{k m}$ を各荷重と構造物ごとに仮定し，表一5に 示す 25 個の構造物を考える.

$$
d_{k m}=\alpha_{k m} \cdot \bar{m} \quad\left(\begin{array}{l}
m=D, L, W, E \\
k=1,2, \cdots \cdots, 25
\end{array}\right)
$$

各構造物 $S_{k}(k=1,2, \cdots \cdots, N)$ におけるこのパラ メーター $d_{k m}$ は, 各荷重の平均值 $\bar{m}$ による荷重効果を 表わし，表一5に示したようにその大きさをそれぞれ 10 〜 40 として, その合計が 100 になるようにする.つまり, 各構造物ごとに荷重の平均値による占有率（\%）を表わ しており, 荷重効果の比率がこのような範囲にある構造 物あるいは部材に相当する.さらに，部材の材料として 鋼材（SM 50 Y）を考え，現行の設計規準における基本 の許容応力度 $\sigma_{a}=2100 \mathrm{~kg} / \mathrm{cm}^{2}$, および終局限界状態を 表わす公称強度として降伏強度 $\sigma_{y}=3600 \mathrm{~kg} / \mathrm{cm}^{2}$ を設 定する.

\section{（2）許容応力度設計法と荷重係数法との比較}

許容応力度設計法と求める荷重係数体系の設計法とを 比較するために，表一2に示した設計照査式の中から現 行の規定に相当するのと同じ種類の Code-1, $-3,-4$ の 3 つのみを取り出し，これに含まれる荷重係数あるいは 設計安全率の最適値を求める.ただし, 最適値の収束精 度を 0.05 までとする. 
まず，現行の設計規準におけるこれらの設計荷重組合 せケースの設計安全率と許容応力度の割増し率を引用 し, 式（1）に示した限界状態 $\sigma_{y}=3600 \mathrm{~kg} / \mathrm{cm}^{2}$ の照 査に対する荷重係数に換算すると，一例として表一6の 左側に示すようになっている(これを計算ケース(1)とす る).ただしここでは現行の設計規準について定量的 な検討を試みるものではなく，あくまで経験的な判断に 基づいて定めた設計安全率や設計荷重組合せの例題とし てこれらの值を引用する.

そこで, 表一6の左側に示した結果を用いて構造物 $S_{k}(k=1,2, \cdots \cdots, 25)$ を設計し, 部材断面の大きさ $Z_{k v}$ と限界状態確率 $P^{(k)}$ を求好と, それぞれ図一6 と 図一7のようになる. 図一7に示す点線 $\bar{P}$ は求めた 25 個の限界状態確率 $P^{(k)}$ を相乗平均したもので，ここでは 荷重係数を求めるための目標値 $P^{*}$ としてこの值を用い る.

次に, 同じくCode-1，-3，-4 のみに着目してこれに

\section{表一 6 設計安全率の検討}

\begin{tabular}{|c|c|c|c|}
\hline & \multicolumn{2}{|c|}{ 計算ケース (1) } & 計算ケース(3) \\
\hline & 設計荷重組合せ & 荷重係数への换算值 & 計 算 值 \\
\hline Code- 1 & $D^{*}+L^{*}$ & $\frac{3600}{2100 \times 1.00}=1.714$ & 1.65 \\
\hline Code- 3 & $D^{*}+E^{*}$ & $\frac{3600}{2100 \times 1.70}=1.008$ & 1.55 \\
\hline Code- 4 & $D^{*}+L^{*}+W^{*}$ & $\frac{3600}{2100 \times 1.25}=1.371$ & 1.15 \\
\hline
\end{tabular}

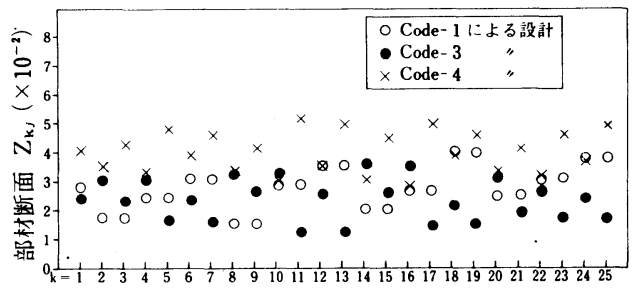

構造物 $\mathrm{S}_{k}$

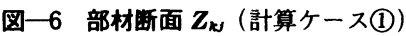

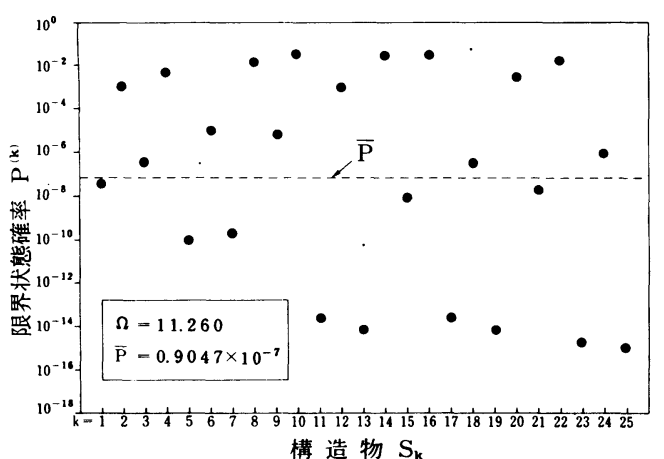

因一7 限界状態梓率 $\boldsymbol{P}^{(\boldsymbol{N})}$ (計算ケース(1)
含まれる荷重係数を求めるにあたり，ステップ(4)-1〜 (6) -2 までの繰り返し回数 $n$ と式 $(12)$ の $\Omega^{\prime}$ の変化およ び各 Code- $j$ に関係する構造物の数を図一8に示す.こ こで, $n=1$ では各 Code- $j$ に対してそれぞれ 25 個の構 造物すべてを用いて設計し， $n=2,3, \cdots \cdots$..において次々 と関係する構造物の数を減らし, 最終の $n=5$ では各構 造物 $S_{k}$ と各 Code- $j$ とは一対一に対応している.また, 得られた荷重係数を表一7にまとめて示す，さらに，表 一7の結果（これを計算ケース(2)とする）を用いて各構 造物 $S_{k}$ の部材断面の大きさ $Z_{k v}$ と限界状態確率 $P^{(k)}$ と を求め，それぞれ図一 9 と図一10に示す。

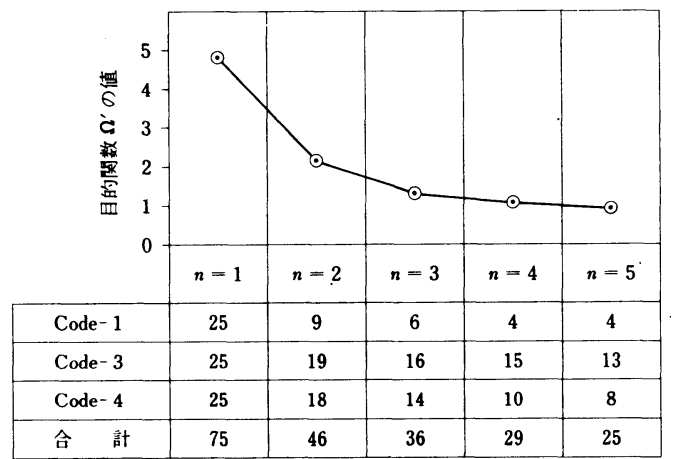

图一8収束計算による $\boldsymbol{\sigma}^{\prime}$ と用いる槽造物数の变化

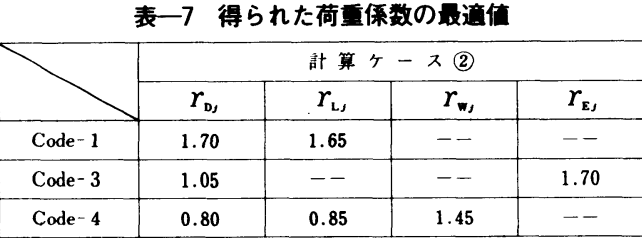

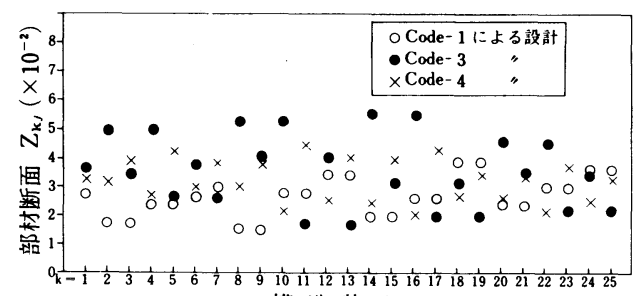
構造物 $\mathrm{S}_{\mathrm{k}}$

図一9 部材断面 $Z_{k}$ （計算ケース(2)

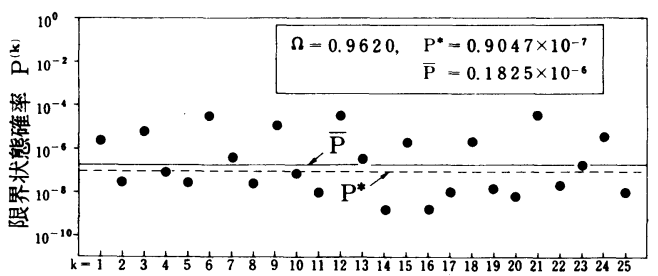

構造物 $\mathrm{S}_{\mathrm{k}}$

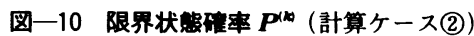




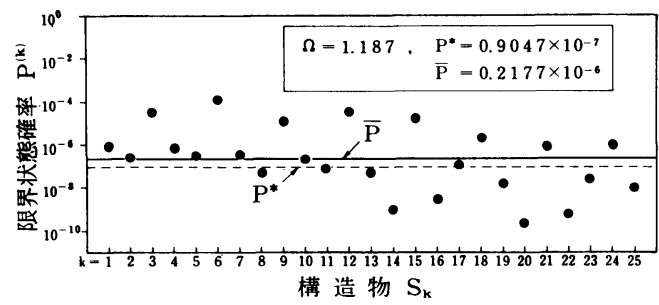

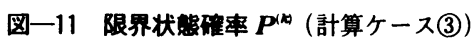

図一7と図一10の結果を比較すると，明らかに荷重係 数を用いた場合の方が限界状態確率の均等化がみられ る.しかしながら，このことは単に荷重係数体系の設計 照査式を用いることによるものではなく，各荷重係数を 信頼性評価に基づいて最適化したことによる．というの は，現行設計法と同じく各設計荷重組合せに対して単一 の設計安全率を用いる場合（これを計算ケース(3)とす る),つまり式（1）の $\gamma_{m}$ を各Code- $j$ ごとに同じに した場合の最適値を求め,これを表一6の右側に示すと ともに，これを用いて各構造物 $S_{k}(k=1,2, \cdots \cdots, 25)$ を設計したときの限界状態確率 $P^{(k)}$ を図一11 に示す.

この結果を図一7および図一10 と比較すると，よく均等 化しているといえよう．ただし，図一10 と図一11 の結 果を $\Omega$ の値で比較した場合，単一の設計安全率を用い る場合よりも荷重係数を用いる場合の方が，多少ながら より適切な設計をもたらすことはいうまでもない.

一方, 図一と図一9 の結果に基づいて各構造物の設 計断面を支配する荷重組合せについてみると，図一6の 結果では多くが Code-4 で断面が決まっているのに対し て, 図一9 の結果では Code-1，-3，-4 が比較的均等に 出現している. また，表一1に示した Load-0 Load-7 の実荷重組合せが，図一7，10，11 に示した各構造物の 各限界状態確率を支配している個数を表一8に示す。こ れによると, Load-0～Load-2 は各構造物の信頼性に与 える影響が小さく, Load-3〜Load-7 の荷重組合せが重 要なことを示している．これは，風荷重や地震荷重の影 響が相対的に大きいことによるものであり，この計算例 では現行の設計規準では考虑していない風荷重と地震荷 重の組合せ，さらには活荷重との組合せなどが支配的な 組合せ荷重として出現している．ただし，これらの点は 終局限界状態 $\sigma_{y}=3600 \mathrm{~kg} / \mathrm{cm}^{2}$ に対しての結果であり, 使用限界状態のようにもっと低い応力度レベルにおいて は Load-1 や Load-2 なども重要になると考えられる.

\section{（3）設計荷重組合せの程類の検討}

前項では Code-1，-3，-4 のみを用いて最適な設計照 査式を検討したが，より合理的な照査をするには，他の 設計荷重組合せをも考慮するのが望ましいと思われる. 图一10 と図一11 の比較で示したように，荷重係数では
表一8 各実荷重組合せが支眍的な梅造物の個数

\begin{tabular}{|c|c|c|c|c|c|c|c|}
\hline & \multicolumn{3}{|c|}{ 計算ケース } & & \multicolumn{3}{|c|}{ 計算ヶース } \\
\hline & (1) & (2) & (3) & & (1) & (2) & (3) \\
\hline Load- 0 & 0 & 0 & 0 & Load- 4 & 1 & 6 & 5 \\
\hline Load- 1 & 0 & 0 & 0 & Load- 5 & 4 & 9 & 8 \\
\hline Load- 2 & 0 & 0 & 0 & Load- 6 & 4 & 7 & 7 \\
\hline Load -3 & 8 & 1 & 1 & Load- 7 & 8 & 2 & 4 \\
\hline
\end{tabular}

表一9 得られた設計安全事の比較

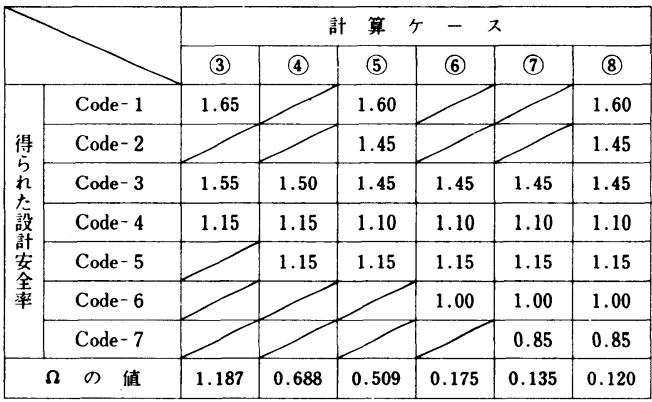

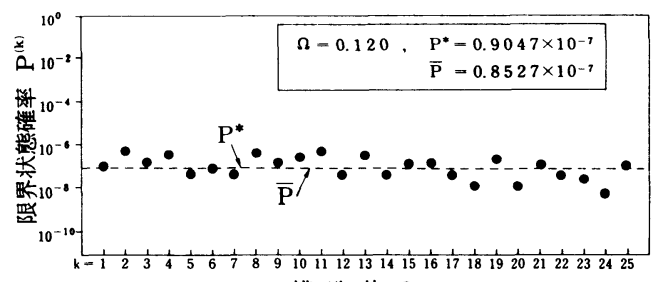

構造物 $\mathrm{S}_{\mathrm{k}}$

图一12 限界状態磪毫 $\boldsymbol{P}^{(\boldsymbol{k})}$ (計算ケース(8)）

なく設計安全率を用いても十分に構造物の信頼性を均等 化することが可能と考えられるため，ここでは最適な設 計安全率を評価することによって，表一2に示した Code-1 Code-7 のうち考虑すべき設計荷重組合せの種 類について検討する.

Code-1 Code-7 のうち，考虑するものに対してそれ ぞれ最適な設計安全率を求め, それらの值とこれを用い て設計した構造物の限界状態確率から得られる $Q$ の值 とを表一 9 にまとめて示す.それぞれ計算ケース(4)〜8) とし，前記した計算ケース(3)の結果をもあわせて示す. 表中の斜線は，設計照査式として考慮しないことを表わ す.これによると，当然ながら計算ケース(8)の $\boldsymbol{S}$ が最 も小さく, その場合の各構造物 $S_{\boldsymbol{k}}$ の限界状態確率 $P^{(k)}$ は図一12のようになり，非常によく均等化している.

しかしながら，設計法としての実用性からすると Code-1 Code-7 のすべてを使用するのではなく，でき るだけ考虑する設計荷重組合せの種類を減らす方が望ま しい.この点に関しては，最終的に設計規準を策定する 委員会の判断によらねばならないが，そのための判断基 準として表一9のような結果が必要になるものと思われ 
る.

ここでの計算例に限ってみると, 終局限界状態 $\sigma_{y}=$ $3600 \mathrm{~kg} / \mathrm{cm}^{2}$ に対して Code-1 や Code-2 はあまり有意 でない,さらに, Code-6 と Code-7 のどちらか 1 つは 考慮する必要があろう. Code-6 と Code-7 の荷重組合 せは現行の設計規準にはなく，今後このような設計荷重 の組合せケースを検討するうえで，本研究の評価手法が 有用になるものと思われる.このように，この手法では 荷重係数だけでなく，単一の設計安全率やさらには許容 応力度の割増し率の検討にも用いることができる.

\section{5. まと め}

本研究では, 組合せ荷重を受ける構造物の信頼性評価 に基づき，設計照査に必要な設計荷重組合せの種類と荷 重係数を評価する手法を検討した。得られた成果と今後 の課題とをまとめる.

（1）構造物の限界状態確率を目標値のまわりに均等 化するという考え方に基づき, 設計荷重の組合せと最適 な荷重係数を評価する手法を示した。

（2）本手法は荷重係数だけでなく，単一の設計安全 率や現行の設計法にみられる許容応力度の割増し率を検 討する場合にも有用なことを示した。

（3）これにより, 限界状態設計法の導入にあたって, 従来より経験工学的に評価している設計安全率や必要な 荷重組合せの種類を設定するうえで，荷重のばらつきを 考虑して数値的に評価することが可能となった。

（4）しかしながら，本研究の考え方では目標とする 限界状態確率を超える構造物が出現するため，より確実 に構造物の信頼性を保証するという点からすると，限界 状態確率の上限値を設けることによりこの点を改善する 必要がある.

（5）さらに，本研究では非常に簡単化した荷重と構 造物のモデルを仮定して計算したが，今後はより実際的 なモデルを用いての検証が必要かと思われる．特に，荷 重のモデルを正確に設定する必要があるとともに，荷重 以外の不確定要因についても配虑することが今後の課題 である.

謝 辞：本論文は, 数年来より橋梁の信頼性評価を 目的として，著者らが本州四国連絡橋公団より委託を受 けた一連の研究成果の一部をとりまとめたものである. 研究にあたって多大なご指導をいただいた小西一郎京都 大学名誉教授，ならびに本州四国連絡橋公団の村上永一 氏(現・石川島播磨重工業), 吉田厳氏，松村 存氏 (現・日本橋梁)，今中靖雄氏 (現・神戸製鋼所)，佐伯 彰一氏，田中淳之氏，松本弘輝氏，北川 信氏，加島
聰氏，その他ご協力いただいた関係各位に謝意を表しま す.

\section{参考 文 献}

1）日本道路協会：道路橋示方書・同解説，丸善，昭和 55 年 2 月.

2） 高岡宣善：構造物の限界状態設計法，土木学会誌，第 61 巻 5 号, 1976 年 5 月.

3）土木学会構造工学委員会・構造物安全性研究小委員会： 構造物の安全性・信頼性, 1976 年 10 月.

4) BSI : Steel, Concrete and Composite Bridges, BS 5400, London, 1978.

5) MTC : Ontario Highway Bridge Design Code, Ontario, 1983.

6）土木学会コンクリート委員会：昭和 61 年制定コンクリー 卜標準示方書, 土木学会, 昭和 61 年 10 月.

7）日本道路協会棉梁委員会：限界状態設計法分科会荷重検 討班第一次報告書, 昭和 61 年 11 月.

8) Lind, N.C. : Consistent Partial Safety Factors, ASCE, ST 6, June 1971.

9) CIRIA Report 63 : Rationalisation of Safety and Serviceability Factors in Structural Codes, London, July 1977.

10) Ellingwood, B., Galambos, T.V., MacGregor, J.G. and Cornell, C. A. : Development of Probability Based Load Criterion for American National Standard A 58, NBS, June 1980.

11) Emi, S. and Aketa, O. : Probabilistic Load and Resistance Factor Design, Proc. of ICOSSAR 85, Kobe, May 1985.

12）川谷充郎・箖塚正宣：限界状態超過確率に基づく荷重係 数, I-163, 土木学会第 41 回年次学術講演会, 昭和 61 年 11 月.

13）若林慎司・北浦 勝・池本敏和：橋梁下部構造への荷重 係数設計法の適用に関する一考察, 土木学会第 41 回年次 学術講演会, I-144, 昭和 61 年 11 月.

14）北沢正彦・久保雅邦・白木 渡 - 亀田弘行：銅製橋脚に おける荷重組合せの解析と荷重係数の試算, 構造工学詥 文集, Vol. 33 A, 1987 年 3 月.

15) Shinozuka, M. : Load Combination and Load Resistance Factor Design, Proc. of IABSE Symposium, Tokyo, Sept. 1986.

16）大橋昭光：荷重係数設計法について，道路，1979 年 6 月.

17）藤野陽三：確率論に基づく安全性照査法と構造設計, 土 木学会誌, 第 63 巻 2 号, 1978 年 2 月.

18) Wen, Y.K. : Statistical Combination of Extreme Loads, ASCE, ST 5, May 1977.

19）久保雅邦・明田 修・渡辺光弘・北沢正彦：時間的に変 動する荷重の組合せモデルについて，土木学会関西支部 年次学術講演会, I-28, 昭和 61 年 5 月.

20）阪神高速道路公団・阪神高速道路管理技術センター：阪 神高速道路の設計荷重体系に関する調査研究, 昭和 61 年 12 月.

（1987.3.11・受付） 